\title{
Penerapan Metode Cooperative Integrated Reading And Composition Dengan Media Audio-Visual Untuk Meningkatkan Kemampuan Menulis Teks Berita Pada Siswa Sekolah Menengah Pertama
}

\author{
Legiana Sinaga ${ }^{1}$ \\ ${ }^{1}$ SMP Negeri 2 Garoga, Tapanuli Utara
}

\begin{abstract}
ABSTRAK
Penelitian ini bertujuan untuk mendeskripsikan penerapan metode CIRC (Cooperative Integrated Reading and Composition) dengan media audio-visual untuk: (1) meningkatkan keaktifan siswa dalam menulis teks berita pada siswa kelas VIII B SMPN 2 Garoga dan (2) untuk meningkatkan kemampuan menulis teks berita siswa pada siswa kelas VIII B SMP N 2 Garoga. Penelitian ini merupakan Penelitian Tindakan Kelas (PTK) yang dilakukan di SMP Negeri 2 Garoga dengan subjek siswa kelas VIII B yang berjumlah 32 siswa. Berdasarkan hasil penelitian terbukti bahwa terjadi peningkatan kualitas pembelajaran yaitu peningkatan keaktifan siswa maupun kemampuan menulis teks berita siswa. Peningkatan keaktifan proses pembelajaran yang ditandai dengan meningkatkanya keaktifan siswa pada siklus I dengan nilai rerata sebesar 16,25 dan nilai rerata pada siklus II sebesar 18,93 dengan nilai rerata maksimal sebesar 25. Peningkatan kemampuan menulis teks berita ditandai dengan meningkatnya ketuntasan belajar siswa, yaitu nilai rerata pada siklus I sebesar 77, 31 dan nilai rerata pada siklus II sebesar 81,37. Kesimpulan dari penelitian ini adalah metode CIRC (Cooperative Integrated Reading and Composition) dengan media audio visual efektif diterapkan dalam pembelajaran menulis teks berita.
\end{abstract}

Kata Kunci: Cooperative Integrated Reading and Composition, media audio-visual, menulis teks berita

\section{PENDAHULUAN}

Mata Pelajaran bahasa Indonesia merupakan salah satu pelajaran wajib di Sekolah Menengah Pertama (SMP). Menulis merupakan keterampilan berbahasa yang harus diajarkan pada siswa. Terkait dengan keterampilan menulis, siswa dituntut agar mampu menyusun dan mengorganisasikan pemikiran, ide dan perasaaan dalam berbagai bentuk tulisan baik sastra maupun non sastra, salah satunya adalah menulis teks berita. Sebagai keterampilan berbahasa yang paling kompleks, menulis menjadi keterampilan berbahasa yang paling kurang diminati oleh siswa karena mereka menyadari bahwa menulis menuntut sejumlah kemampuan.

Keterampilan menulis sebagai salah satu komponen dari keterampilan berbahasa mempunyai peran penting dalam kehidupan. Menurut Nurudin (2010:19-27) menulis bermanfaat untuk (1) sarana mengungkapkan diri, yakni bahwa dengan menulis bisa mengungkapkan perasaan hati (kegelisahan, keinginan, kemarahan dan lain-lain); (2) sarana pemahaman, yakni menulis sebenarnya menancapkan pemahaman kuat dalam otak penulis; (3) membantu mengembangkan kepuasan pribadi, kebanggaan, perasaan harga diri; (4) meningkatkan kesadaran dan penyerapan terhadap lingkungan; (5) keterlibatan secara bersemangat dan bukannya penerimaan yang pasrah; (6) mengembangkan suatu pemahaman tentang dan kemampuan menggunakan bahasa.

Keterampilan menulis teks berita merupakan salah satu Kompetensi Dasar mata pelajaran bahasa Indonesia di kelas VIII Semester I, dengan Standar Kompetensi (SK) yaitu mengungkapkan informasi dalam bentuk rangkuman, teks berita, slogan/poster. Kompetensi Dasar (KD) yang harus dicapai adalah menulis teks berita secara singkat, padat, dan jelas. Menulis teks berita merupakan salah satu kompetensi berbahasa yang harus dikembangkan. Setelah mengikuti kegiatan pembelajaran menulis teks berita, siswa diharapkan dapat menyusun data pokok berita, mampu merangkai data-data pokok berita menjadi berita yang singkat, padat, dan jelas.

Dalam proses pembelajaran siswa dituntut aktif, dimana siswa banyak melakukan kegiatan, sedangkan guru lebih banya membimbing dan mengarahkan. Menurut Yamin (2007: 80- 
81) menjelaskan bahwa keaktifan siswa dapat dilaksanakan manakala: (1) pembelajaran yang dilakukan lebih berpusat pada siswa, (2) guru berperan sebagai pembimbing supaya terjadi pengalaman dalam belajar, (3) tujuan kegiatan pembelajaran tercapai kemampuan minimal siswa (kompetensi dasar), (4) pengelolaan kegiatan pembelajaran lebih menekankan pada kreativitas siswa, meningkatkan kemapuan minimalnya, dan mencapai siswa yang kreatif serta mampu menguasai konsep-konsep, dan (5) melakuan pengukuran secara kontinu dalam berbagai aspek pengetahuan, sikap, dan keterampilan.

Siswa aktif adalah siswa yang terlibat secara intelektual dan emosional dalam kegiatan belajar (Ahmadi \& Supriyono, 2004: 207). Siswa aktif adalah siswa yang terlibat secara fisik, psikis, intelektual dan emosional secara terus menerus dalam proses pembelajaran (Yusmiati, 2010: 10). Keaktifan siswa dalam proses pembelajaran tidak hanya keterlibatan dalam bentuk fisik seperti duduk melingkar, mengerjakan/ melakukan sesuatu, akan tetapi dapat juga dalam bentuk proses analisis, analogi, komparasi, penghayatan, yang kesemuanya merupakan keterlibatan siswa dalam hal psikis dan emosi (Sugandi, 2007: 75). Dari pengertian-pengertian tersebut dapat disimpulkan bahwa siswa aktif adalah siswa yang terlibat secara terus menerus baik secara fisik, psikis, intelektual maupun emosional dalam proses pembelajaran.

Meskipun keseharian kita sudah akrab dengan berita, namun dalam keterampilan menulis teks berita banyak siswa yang masih mengalami kesulitan dalam penulisannya. Selama ini siswa belum mampu menulis berita dengan baik. Hal tersebut dapat dilihat dari hasil evaluasi siswa saat pembelajaran menulis berita. Berdasarkan hasil wawancara dengan guru, masih banyak siswa yang tidak memenuhi kriteria ketuntasan minimal (KKM). Kriteria ketuntasan minimal di SMP Negeri 2 Garoga yaitu sebesar 80. Dari 7 kelas VIII yang terdapat di SMP Negeri 2 Garoga yang memperoleh hasil nilai evaluasi terendah saat pembelajaran menullis teks berita adalah di kelas VIII B.

Berdasarkan hasil observasi di kelas VIII B SMP Negeri 2 Garoga, peneliti menemukan beberapa permasalahan, seperti kurangnya motivasi dan minat siswa dalam mengikuti pelajaran, kesulitan siswa dalam menulis teks berita, siswa kurang aktif dan hanya mendengarkan penjelasan guru kemudian mengerjakan apa yang diperintahkan oleh guru. Pembelajaran yang digunakan oleh guru metode ceramah.

Masalah-masalah yang ada dalam pembelajaran menulis berita membutuhkan metode pembelajaran yang tepat agar dapat meningkatkan kemampuan menulis berita. Metode yang dinilai tepat dan cocok dalam pembelajaran ini adalah metode kooperatif. Metode kooperatif dinilai mampu memotivasi siswa untuk berani mengungkapkan pendapat teman, dan saling memberikan pendapat. Banyak jenis model pembelajaran kooperatif yang digunakan dalam pembelajaran bahasa Indonesia. Peneliti dan guru menyepakati bahwa metode kooperatif yang digunakan dalam pembelajaran menulis berita adalah metode Cooperative Integrated Reading and Composition (CIRC).

Metode CIRC merupakan suatu program komprehensif untuk pengajaran membaca dan menulis pada kelas-kelas tinggi di sekolah menengah pertama dan atas. Siswa bekerja dalam tim belajar kooperatif yang beranggotakan empat orang (Nur, 2005: 12). Siswa terlibat dalam rangkaian kegiatan bersama, saling membacakan satu sama lain, menulis tanggapan terhadap isi bacaan, membuat ikhtisar, berlatih pengejaan, dan pembendaharaan kata. Metode CIRCadalah komposisi terpadu membaca dan menulis secara kooperatif-kelompok (Suyatno, 2009: 68).

CIRC adalah komposisi terpadu membaca dan menulis secara kooperatif- kelompok. Sintaksnya adalah: membentuk kelompok heterogen 4 orang, guru memberikan wacana bahan bacaan sesuai dengan bahan ajar, siswa bekerja sama (membaca bergantian, menemukan kata kunci, memberikan tanggapan) terhadap wacana kemudian menuliskan hasil kolaboratifnya, presentasi hasil kelompok, refleksi. Model kooperatif tipe CIRC terarah pada satu fokus utama, yakni membuat pengguna waktu tindak lanjut menjadi lebih efektif.Siswa bekerja di dalam kelompok kooperatif yang dikoordinasikan dengan pengajaran kelompok membaca, kosakata, dan ejaan.Siswa dituntut oleh seluruh anggota kelompok (Slavin, 2005: 201).

Pada metode ini siswa dibentuk kelompok untuk memberikan tanggapan terhadap wacana dengan langkah langkah sebagai berikut; (1) membentuk kelompok yang anggotanya 4 orang yang secara heterogen, (2) guru memberikan wacana/kliping sesuai dengan topik pembelajaran, (3) siswa bekerjasama saling membacakan dan menemukan ide pokok dan memberi tanggapan terhadap wacana dan ditulis pada kertas, (4) mempresentasikan hasil kelompok, (5) guru membuat kesimpulan, (6) refleksi. 
Salah satu bentuk perbaikan dalam proses pembelajaran selain dengan metode adalah dengan melakukan pengembangan media pembelajaran yang efektif dan tepat sasaran. Hal tersebut sangat memungkinkan sebagai solusi dari permasalahan siswa, khususnya dalam menulis sebuah teks berita. Adapun proses belajar mengajar yang dilakukan guru adalah secara konvensional, yaitu pemberian materi yang berupa teori-teori melalui ceramah satu arah, dan dilanjutkan dengan pemberian tugas. Akibatnya, banyak siswa mengalami kejenuhan saat proses pembelajaran berlangsung.

Penggunaan media pembelajaran memiliki peranan penting dalam proses belajar mengajar. Media pembelajaran merupakan suatu bagian yang tidak dapat dipisahkan dari proses belajar mengajar. Seorang guru haruslah dapat memanfaatkan serta mengoptimalkan sesuatu hal yang ada di sekelilingnya sebagai media dalam proses belajar mengajar. Karena apabila seorang guru sudah dapat melakukan hal tersebut terciptanya suasana pembelajaran yang kondusif tidaklah menjadi sesuatu yang mustahil. Salah satu media pendidikan yang dapat digunakan dalam pembelajaran menulis adalah media audio visual.

Media audiovisual adalah alat bantu dalam pembelajaran yang berhubungan dengan indera penglihatan dan pendengaran. Salah satu media audio visual yang digunakan oleh peneliti dalam penelitian ini adalah rekaman wawancara dalam bentuk audio visual. Penggunaan media ini diharapkan dapat membantu siswa yang memiliki kekurangan secara auditif maupun visual. Meskipun media yang digunakan sederhana, tetapi yang lebih penting memanfaatkan serta mengoptimalkannya dalam proses pembelajaran sehingga tujuan pembelajaran dapat tercapai. Selain itu, media tersebut mudah diperoleh serta di aplikasikan dalam proses pembelajaran, dan tidak memerlukan biaya yang mahal dalam penggunaanya. Penulis menggangap media rekaman wawancara audiovisual ini dapat memotivasi siswa dalam pembelajaran menulis,terutama dalam menulis teks berita. Media rekaman wawancara dalam bentuk audio visual ini diharapkan dapat dengan mudah membantu siswa mengatasai kesulitan dalam penulisan teks berita siswa.

\section{METODE PENELITIAN}

Penelitian ini dilakukan di SMP Negeri 2 Garoga yang beralamat di Kabupaten Tapanuli Utara. Adapun alasan penelitian ini dilaksanakan di SMP Negeri 2 Garoga adalah sebagai berikut: 1) Kompetensi Dasar "Menulis teks berita secara singkat, padat, dan jelas" terdapat di kelas VIII dan dikelas VIII B tersebut terdapat permasalahan pembelajaran menulis teks berita. 2) SMP Negeri 2 Garoga merupakan sekolah yang terbuka dan bersedia menerima segala bentuk penelitian yang berhubungan dengan pendidikan, yang bertujuan untuk meningkatkan kualitas sekolah dan profesionalitas guru.

Subjek penelitian ini adalah siswa kelas VIII B SMP Negeri 2 Garoga. Siswa kelas VIII B berjumlah 32 siswa, terdiri atas 18 siswa perempuan dan 14 siswa laki-laki. Data penelitian dikumpulkan dari berbagai sumber yang meliputi: 1) berlangsungnya proses belajar mengajar yang dilaksanakan oleh siswa kelas VIII B SMP Negeri 2 Garoga; 2) informan, yaitu guru mata pelajaran, dan beberapa siswa kelas VIII B; dan 3) dokumen yang meliputi cacatan hasil observasi selama proses pembelajaran, hasil tes siswa, daftar nilai, rencana pelaksanaan pembelajaran (RPP), cacatan hasil wawancara yang ditranskip, dan foto kegiatan pembelajaran.

Teknik pengumpulan data yang digunakan meliputi: observasi, wawancara, tes atau pemberian tugas. 1) Observasi terhadap guru difokuskan pada kemampuan guru dalam mengelola kelas serta dalam memancing keaktifan siswa dalam pembelajaran menulis teks berita yang sedang berlangsung. Sementara itu, observasi terhadap siswa difokuskan dalam lima indikator, yaitu: keakfifan selama apersepsi, mengajukan pertanyaan dan mengemukakan ide atau gagasan, memperhatikan penjelasan guru, mencatat materi yang dijelaskan guru, aktif dalam diskusi kelompok, dan aktif dalam melaksanakan tugas. 2) Wawancara dengan guru dan siswa dilakukan pada setiap siklus. Teknik ini digunakan untuk memperoleh data dari informan tentang pelaksanaan pembelajaran menulis teks berita di kelas VIII B SMP Negeri 2 Garoga. 3) Tes atau Pemberian Tugas. Dalam penelitian ini, guru melakukan tes atau memberikan tugas untuk mengetahui kemampuan siswa dalam menulis teks berita setelah mengikuti pembelajaran menulis teks berita dengan metode metode CIRC (Cooperative Integrated Reading and Composition) dengan media audio visual. Uji Validitas data menggunakan triangulasi metode dan sumber data. Teknik analisis data yang digunakan untuk menganalisis data yang telah dikumpulkan antara lain dengan menggunakan teknik deskriptif komparatif (statistik deskriptif komparatif) dan teknik analisis kritis. 


\section{HASIL DAN PEMBAHASAN}

Peningkatan kualitas pembelajaran menulis teks berita dinilai dari hasil observasi kinerja siswa selama melaksanakan tindakan prasiklus, siklus I, dan siklus II. Berdasarkan hasil pengamatan, berikut diuraikan peningkatan kinerja siswa. Peningkatan keaktifan siswa selama proses pembelajaran menulis teks berita, mulai dari prasiklus, siklus I, dan siklus II dinilai dari lima indikator, yaitu (1) keaktifan selama apersepsi, (2) mengajukan pertanyaan dan mengemukakan ide atau gagasan, (3) memperhatikan penjelasan guru, (4) mencatat materi yang dijelaskan guru, dan (5) keaktifan mengerjakan tugas. Berdasarkan hasil pengamatan dari prasiklus sampai dengan siklus II, diketahui bahwa indikator tersebut mengalami peningkatan. Pada observasi prasiklus nilai kinerja siswa adalah 12,75 . Pada siklus I rata-rata nilai kinerja adalah 16,25. Dilanjutkan pada siklus II, pembelajaran mulai berubah. Nilai rata-rata kinerja siswa pada siklus II adalah 18,93 dari skor maksimal yaitu 25. Untuk lebih jelasnya, rekapitulasi peningkatan nilai keaktifan siswa dapat dilihat pada gambar 1 .

Gambar 1. Peningkatan Nilai Keaktifan Siswa dalam Mengikuti KBM

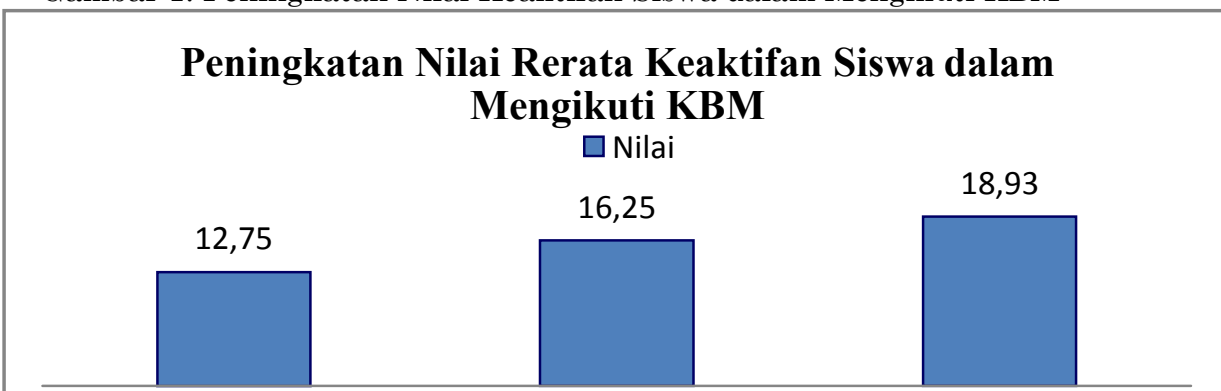

Nilai rata-rata siswa selalu mengalami peningkatan dari prasiklus sampai dengan siklus II. Pada kegiatarPnaisjiktikdus yang dilakukarsikdatuk mengetahui kemsibalps din awal siswa dalam menulis teks berita diperoleh nilai rata-rata kemampuan menulis teks berita adalah 73,24 dengan nilai terendah 58,75 dan nilai tertinggi 87,5 . Pada siklus I, nilai terendah yang dicapai siswa adalah 68,75 , sedangkan nilai tertinggi 87,5 . Rata-rata nilai kemampuan menulis teks berita pada siklus I mencapai 78,67 Pada siklus II, nilai terendah yang dicapai siswa adalah 70, sedangkan nilai tertinggi 90. Rata-rata nilai kemampuan menulis teks berita pada siklus II mengalami peningkatan menjadi 81,37. Nilai rerata tersebut sudah melebihi KKM yang ditentukan yaitu 80 .

Untuk lebih jelasnya, rekapitulasi peningkatan nilai kemampuan memahami unsur intrinsik cerpen siswa dari prasiklus sampai dengan siklus II dapat dilihat pada gambar 2.

Gambar 2. Peningkatan Nilai Kemampuan Menulis Teks Berita

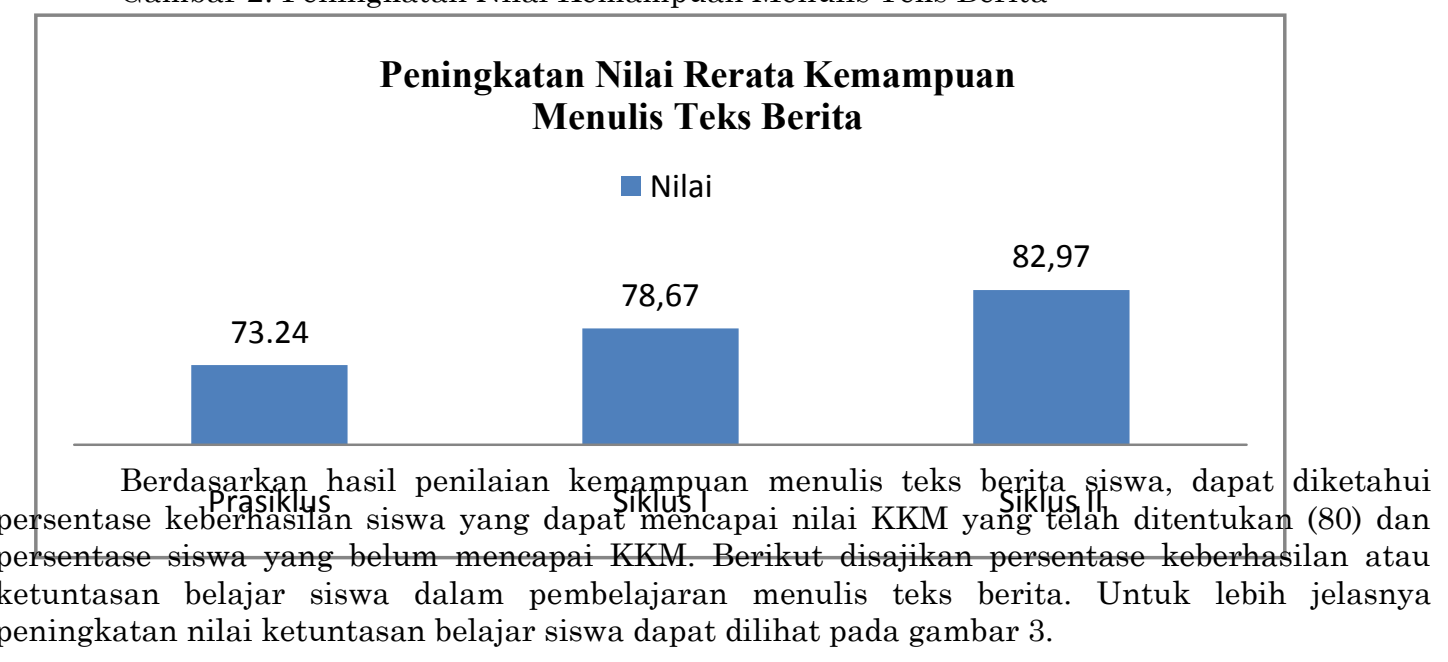

Gambar 3. Peningkatan Persentase Nilai Ketuntasan Belajar Siswa dalam Menulis Teks Berita 


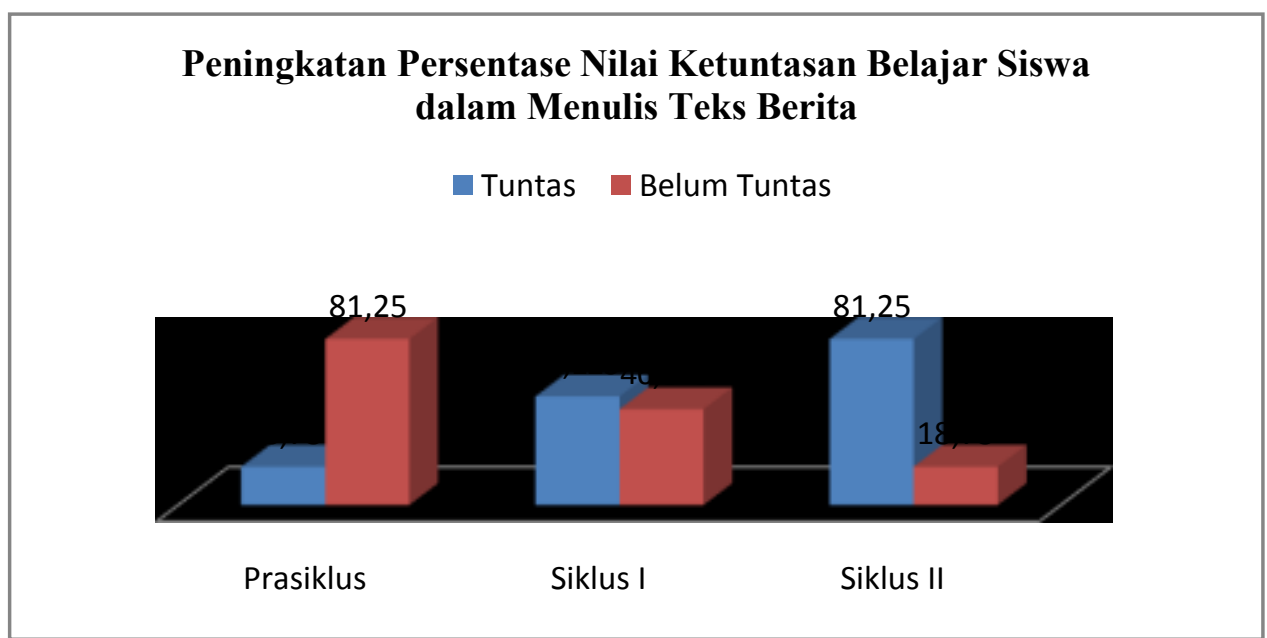

Berdasarkan gambar diagram di atas, dapat dilihat bahwa: (1) persentase jumlah siswa yang mencapai nilai ketuntasan belajar menulis teks berita pada prasiklus sebanyak $18,75 \%(6$ siswa) dan yang belum tuntas sebanyak 81,25\% (26 siswa); (2) persentase jumlah siswa yang mencapai nilai ketuntasan belajar menulis teks berita pada siklus I sebanyak 53,125\% (17 siswa) dan yang belum tuntas $46,875 \%$ (15 siswa); dan (3) persentase jumlah siswa yang mencapai nilai ketuntasan belajar menulis teks berita pada siklus II sebanyak 81,25\% (26 siswa) dan yang belum tuntas $18,75 \%$ (6 siswa).

Tabel 1. Rekapitulasi Peningkatan Nilai proses dan Hasil Belajar Menulis Teks Berita

\begin{tabular}{|c|c|c|c|c|c|}
\hline \multirow[t]{2}{*}{ No. } & \multirow{2}{*}{\multicolumn{2}{|c|}{ Objek Penlilaian }} & \multicolumn{3}{|c|}{ Rata-rata } \\
\hline & & & Prasiklus & Siklus I & Siklus II \\
\hline 1. & Keaktifan Siswa & & 12,75 & 16,25 & 18,93 \\
\hline 2. & $\begin{array}{l}\text { Kemampuan Menulis } \\
\text { Berita }\end{array}$ & Teks & 73,44 & 77,31 & 81,37 \\
\hline
\end{tabular}

Berdasarkan perumusan masalah dan deskripsi hasil pengamatan tindakan, tujuan penelitian serta paparan hasil penelitian, berikut ini dijabarkan pembahasan hasil yang meliputi hal-hal berikut ini.

\section{Peningkatan Keaktifan Siswa}

Meningkatnya keaktifan siswa melalui penerapan metode CIRC (Cooperative Integrated Reading and Composition) dan media audio visual, penerapan metode CIRC (Cooperative Integrated Reading and Composition) dengan media audio visual ternyata memberikan kontribusi yang luar biasa dalam proses pembelajaran meulis teks berita pada siswa kelas VIII B SMP Negeri 2 Garoga. Hal tersebut dibuktikan dengan adanya peningkatan yang cukup signifikan ketika sebelum dan setelah penerapan metode CIRC dengan media audio visual. Setelah diterapkannya metode CIRC dengan media audio visual didapatkan hasil bahwa lebih dari 75\% siswa dapat aktif dalam pembelajaran dengan hasil perolehan nilai yang memuaskan.

Peningkatan kualitas pembelajaran menulis teks berita dinilai dari hasil observasi keaktifan siswa selama melaksanakan tindakan prasiklus, siklus I, dan siklus II. Berdasarkan hasil pengamatan, berikut diuraikan peningkatan kinerja siswa. Peningkatan keaktifan siswa selama proses pembelajaran menulis teks berita, mulai dari prasiklus, siklus I, dan siklus II dinilai dari lima indikator, yaitu (1) keaktifan selama apersepsi ,(2) mengajukan pertanyaan dan mengemukakan ide atau gagasan, (3) memperhatikan penjelasan guru, (4) mencatat materi yang dijelaskan guru, dan (5) keaktifan mengerjakan tugas.Keaktifan siswa juga bertambah dalam pembelajaran menulis teks berita. Siswa lebih aktif dalam mengeluarkan pendapat maupun aktif saat berdiskusi. Penggunaan metode CIRC dengan media audio visual merupakan salah satu variasi metode mengajar yang membuat siswa aktif dan diyakini mampu meningkatkan 
kesuksesan siswa dan keterampilan pembelajaran lebih baik daripada metode pembelajaran tradisional.

Hal di atas dapat tercapai dengan baik karena adanya interaksi yang bagus antara guru dan siswa dalam proses pembelajaran. Juga ketepatan strategi pembelajaran menjadi salah satu faktor penting keberhasilan penelitian ini. Ini diharapkan dapat memaksimalkan kemampuan siswa dalam belajar, sehingga apa yang menjadi tujuan bersama dalam proses belajar-mengajar dapat tercapai dan memberikan manfaat yang luar biasa bagi siswa dan juga guru. Berdasarkan hal tersebut dapat dikatakan bahwa penerapan metode CIRC dengan media audio visual memang terbukti sangat efektif dan tepat digunakan dalam meningkatkan keaktifan dan kemampuan siswa dalam menulis teks berita siswa kelas VIII B SMP Negeri 2 Garoga.

\section{Peningkatan kemampuan menulis teks berita}

Peningkatan kemampuan menulis teks berita siswa kelas VIII B SMP Negeri 2 Garoga melalui penerapan metode CIRC (Cooperative Integrated Reading and Composition) dan media audio visual, metode pembelajaran yang inovatif dan pemanfaatan media yang sesuai turut mempengaruhi ketercapaian kompetensi tersebut.

Metode pembelajaran merupakan unsur penting keberhasilan guru dalam mengajar. Dengan menguasai beberapa metode pembelajaran, maka seorang guru dapat menerapkan metode pembelajaran yang bervariatif sehingga tujuan pembelajaran yang hendak dicapai dalam proses pembelajaran dapat tercapai. Tindakan dalam penelitian ini adalah pembelajaran menulis teks berita menggunakan metode CIRC dengan media audio visual.

Kegiatan belajar mengajar menulis teks berita dengan menggunakan metode CIRC dan media audio visual dilaksanakan dalam dua siklus. Siklus I dan siklus II masing-masing dilaksanakan dalam dua pertemuan. Berdasarkan hasil pengamatan dan analisis pada prasiklus, siklus I, dan siklus II dapat dikemukakan bahwa pembelajaran dengan menggunakan metode CIRC dengan media audio visual pada siswa kelas VIII B SMP Negeri 2 Garoga mengalami peningkatan. Peningkatan tersebut meliputi peningkatan kualitas proses pembelajaran yaitu meningkatnya keaktifan siswa dan hasil pembelajaran yang dapat dilihat dari peningkatan kemampuan menulis teks berita siswa.

Metode CIRC (Cooperative Integrated Reading and Composition) tepat digunakan dalam pembelajaran menulis teks berita karena dengan pembelajaran kooperatif kondisi kelas dapat menjadi dinamis karena interakasi terjadi multi arah. Peran teman sebaya dalam belajar bersama memegang peranan penting untuk memunculkan motivasi siswa dalam memahami pembelajaran. Media audiovisual tepat digunakan dalam pembelajaran menulis berita karena dengan media audiovisualberupa videoakan membantu siswa dalam berimajinasi mencatat poin-poin yang penting dan selanjutnya menuangkan ide-ide dan gagasannya ke dalam bentuk tulisan teks berita.

\section{KESIMPULAN}

Penerapan metode CIRC (Cooperative Integrated Reading and Composition) dengan media audio visual dapat meningkatkan kualitas proses belajar pada pembelajaran menulis berita. Hal tersebut ditandai melalui peningkatan rerata nilai kinerja siswa. Nilai rerata kinerja siswa pada prasiklus adalah 12,75 dari nilai maksimal 25 dengan kriteria sedang, pada siklus I adalah 16,25 dari nilai maksimal 25 dengan kriteria sedang, pada siklus II adalah 18,93 dari nilai maksimal 25 dengan kriteria baik.

Penerapan metode CIRC (Cooperative Integrated Reading and Composition) dengan media audio visual dapat meningkatkan kemampuan siswa dalam menulis teks berita. Dengan kata lain, penerapan metode CIRC (Cooperative Integrated Reading and Composition) dengan media audio visual dapat meningkatkan kemampuan menulis teks berita pada siswa kelas VIII B SMP Negeri 2 Garoga. Peningkatan tersebut dapat dilihat dari peningkatan rata-rata nilai kemampuan menulis teks berita dan persentase ketuntasan belajar pada setiap siklusnya. Pada prasiklus nilai rata-rata tes kemampuan menulis teks berita mencapai 73,44 dengan persentase ketuntasan belajar 18,75\%. Pada siklus I nilai rata-rata tes kemampuan menulis teks berita mencapai 77,31 dengan persentase ketuntasan belajar 53,125\%. Pada Siklus II nilai rata-rata tes kemampuan memahami unsur intrinsik cerpen 81,375 dengan persentase ketuntasan belajar $81,25 \%$.

Metode pembelajaran CIRC (Cooperative Integrated Reading and Composition) dengan media audio visual dapat digunakan sebagai bahan pertimbangan bagi guru dalam 
memberikan materi menulis teks berita kepada siswa. Dilihat dari segi proses, penggunaan metode pembelajaran CIRC (Cooperative Integrated Reading and Composition) dengan media audio visual dapat meningkatkan keaktifan siswa dalam diskusi kelompok dan minat menulis teks berita siswa. Dari segi hasil penggunaan metode pembelajaran CIRC (Cooperative Integrated Reading and Composition) dengan media audio visual dapat meningkatkan kemampuan pembelajaran menulis teks berita siswa. Peningkatan tersebut dapat dilihat dari hasil kerja siswa dalam menulis teks berita. Langkah-langkah efektif yang dapat dilakukan dalam pengoptimalan metode pembelajaran CIRC (Cooperative Integrated Reading and Composition) dengan media audio visual dalam pembelajaran menulis teks berita meliputi: (1) memperbaiki keterampilan guru dalam mengelola kelas, (2) memilihkan video atau media audio visual yang menarik dan dekat dengan dunia siswa, (3) membentuk kelompok yang heterogen, (4) melatih siswa untuk bertanggung jawab dengan tugas yang sudah dibagi, dan (5) melatih siswa untuk mampu menulis teks berita dengan baik.

Melihat penjelasan tersebut dapat ditarik kesimpulan bahwa dengan menggunakan metode pembelajaran CIRC (Cooperative Integrated Reading and Composition) dengan media audio visual dapat meningkatkan kemampuan menulis teks berita siswa kelas VIII B SMP Negeri 2 Garoga Tahun Ajaran 2019/2020. Metode CIRC (Cooperative Integrated Reading and Composition) tepat digunakan dalam pembelajaran menulis teks berita karena dengan pembelajaran kooperatif kondisi kelas dapat menjadi dinamis karena interakasi terjadi multi arah. Peran teman sebaya dalam belajar bersama memegang peranan penting untuk memunculkan motivasi siswa dalam memahami pembelajaran. Media audiovisual tepat digunakan dalam pembelajaran menulis berita karena dengan media audiovisualberupa videoakan membantu siswa dalam berimajinasi mencatat poin-poin yang penting dan selanjutnya menuangkan ide-ide dan gagasannya ke dalam bentuk tulisan teks berita.

\section{DAFTAR PUSTAKA}

Ahmadi, A. \& Supriyono W. (2004). Psikologi Belajar. Jakarta: Rineka Cipta.

Dalman, H. (2014). Keterampilan Menulis. Jakarta: PT Raja grafindo Persada

Martinus, Y. (2007). Keaktifan dalam Pembelajaran. Jakarta: Raja Gra findo Persada.

Munadi, Y. (2010). Media Pembelajaran: Sebuah Pendekatan Baru. Jakarta: GaungPersada Press.

Nurudin. (2010). Dasar-Dasar Penulisan. Malang: UMM Press.

Slavin, R. (2005). Cooperative Learning Teori, Riset, danPraktik. Bandung: Nusa Media.

Samsudin, A. (2011).Peningkatan Kemampuan Menulis Eksposisi Berita dan Menulis Eksposisi Ilustrasi Siswa Kelas V Melalui Model Pembelajaran Kooperatif Terpadu Membaca dan Menulis.Jurnal Penelitian Pendidikan. 13 ( 2)1-9.

Sugandi, A. (2004). TeoriPembelajaran. Semarang: UNNES Press.

Suyanto. (1998). Keterampilan Berbahasa Membaca-Menulis-Berbicara untuk Mata Kuliah Dasar Umum Bahasa Indonesia. Jakarta: Departemen Pendidikan dan Kebudayaan.

Sumadiria, H. (2005). Jurnalistik Indonesia Menulis Berita dan Feature. Bandung: Simbiosa Rekatama Media.

Wibawa, Basuki \& Farida M. (2001). Media Pengajaran. Bandung: CV Maulana 